\title{
Interactions in a Methane-utilizing Mixed Bacterial Culture in a Chemostat
}

\author{
By J. D. LINTON AND J. C. BUCKEE \\ Shell Research Limited, Sittingbourne Research Centre, \\ Shell Biosciences Laboratory, Sittingbourne, Kent ME9 8AG
}

(Received I4 January 1977; revised 23 March 1977)

The interactions between the component species of a mixed bacterial culture grown on methane were investigated. The culture contained the methane-utilizing bacterium Methylococcus sp. and four heterotrophic bacteria which were unable to grow on methane but utilized products released by lysis of the Methylococcus sp. Products of methane oxidation such as methanol, formaldehyde and formate did not constitute a significant amount of the organic carbon found in the culture supernatant of the pure methane-utilizing bacterium grown in chemostat culture. The organic carbon was accounted for mainly as protein and nucleic acid and originated from a growth-dependent lysis of the methane-utilizing bacterium. In the mixed culture the level of the organic carbon was reduced and it is suggested that extracellular enzymes produced by the heterotrophic bacteria play a role in the degradation and utilization of these compounds. The major heterotrophic bacterium Pseudomonas sp. NCIBI 310 produced an extracellular neutral protease that degraded the proteins present in the culture supernatant of the methane-utilizing bacterium.

\section{INTRODUCTION}

Process routes for single-cell protein production from both methane and methanol, employing defined mixed bacterial populations, have been proposed (Harrison, Topiwala \& Hamer, 1972; Hamer et al., 1976). Mixed cultures growing on methane as the sole source of carbon and energy grow better and exhibit greater stability than pure cultures (Sheehan \& Johnson, I97 ; Harrison et al., 1975). The instability of pure cultures growing on methane may be due to the accumulation of inhibitory intermediate oxidation products of methane which are removed by the heterotrophic bacteria present in mixed cultures (Wilkinson \& Harrison, 1973). Indeed, growth of a methane-utilizing pseudomonad in pure culture is inhibited by the accumulation of methanol (Wilkinson \& Harrison, 1973). In a stable mixed culture system, the methanol produced by the methane-utilizing pseudomonad was utilized by a Hyphomicrobium sp. and it was suggested that the role of the other two organisms, an Acinetobacter sp. and a Flavobacterium sp. was to remove complex biological growth or cell lysis products (Wilkinson \& Harrison, I973; Wilkinson, Topiwala \& Hamer, 1974). This paper reports a study of the interactions between component species of a different mixed culture grown on methane as the sole source of carbon and energy.

\section{METHODS}

Mixed culture. A mixed culture was obtained from a mud sample taken from the tropical duck pond at Slimbridge, Gloucestershire, using continuous flow enrichment in chemostat culture with a basal salts medium and methane as the sole source of carbon and energy. The culture comprised a methane-utilizing bacterium (Methylococcus sp. NCIBI 1083), and eight heterotrophic bacteria that were unable to grow on 
methane. The component organisms were isolated and the culture was reconstituted with four of the heterotrophic bacteria and the Methylococcus sp. The four heterotrophic bacteria are deposited at the National Collection of Industrial Bacteria, Aberdeen, and have been identified as Pseudomonas sp. NCIBI I 3 IO, Mycobacterium/Nocardia sp. NCIBI I307, Moraxella sp. NCIBI 1308 and a second Pseudomonas sp. NCIBII 309 (given in descending order of numerical frequency in the mixed culture).

Media and growth conditions. The basal medium ( $\mathrm{pH} 6 \cdot 8)$ contained, in a final volume of $\mathrm{I} 1:\left(\mathrm{NH}_{4}\right)_{2} \mathrm{SO}_{4}$, I.45 g; $\mathrm{H}_{3} \mathrm{PO}_{4}, \mathrm{I} \cdot 09 \mathrm{~g} ; \mathrm{MgSO}_{4} .7 \mathrm{H}_{2} \mathrm{O}, 0.099 \mathrm{~g} ; \mathrm{CaCl}_{2} .2 \mathrm{H}_{2} \mathrm{O}, 0.015 \mathrm{~g}$; trace element mixture, I ml from a solution containing $\left(\mathrm{g} \mathrm{1}^{-1}\right): \mathrm{ZnSO}_{4} .7 \mathrm{H}_{2} \mathrm{O}, 0.288 ; \mathrm{MnSO}_{4} .4 \mathrm{H}_{2} \mathrm{O}, 0.224 ; \mathrm{H}_{3} \mathrm{BO}_{3}, 0.062 ; \mathrm{CuSO}_{4} .5 \mathrm{H}_{2} \mathrm{O}$, $0 . \mathrm{I} 25 ; \mathrm{Na}_{2} \mathrm{MoO}_{4} \cdot 2 \mathrm{H}_{2} \mathrm{O}, 0.048 ; \mathrm{CoCl}_{2} .6 \mathrm{H}_{2} \mathrm{O}, 0.048 ; \mathrm{KI}, 0.083$; plus I M- $\mathrm{H}_{2} \mathrm{SO}_{4}, \mathrm{I} \mathrm{ml}$ and $\mathrm{FeSO}_{4} .7 \mathrm{H}_{2} \mathrm{O}$, I $\mathrm{ml}$ from a solution containing $9 \cdot 26 \mathrm{~g} \mathrm{1}^{-1}$.

Lysate broth was made by sonicating a suspension of Methylococcus sp. in basal salts medium using an MSE ultrasonic disintegrator $(5 \times \mathrm{I} \mathrm{min})$ at $4{ }^{\circ} \mathrm{C}$, and then diluting the suspension with basal salts medium to give a final concentration of approximately $0.8 \mathrm{~g}$ carbon $1^{-1}$.

An impeller-stirred (1 $200 \mathrm{rev}$. $\mathrm{min}^{-1}$ ) Biotec fermentation vessel (LKB Instruments) of 21 working volume was used. The temperature was maintained at $42 \pm 0.25^{\circ} \mathrm{C}$ and the culture $\mathrm{pH}$ was controlled at $6.8 \pm 0 . \mathrm{I}$ by adding $0.5 \mathrm{M}-\mathrm{NaOH} / \mathrm{KOH}$. Methane, containing $\mathrm{CO}_{2}(\mathrm{I} \cdot 5 \%), \mathrm{N}_{2}(0.5 \%)$ and argon plus oxygen $(0.5 \%)$ was supplied to the chemostat at $300 \mathrm{ml} \mathrm{min}^{-1}$ and air was supplied at $900 \mathrm{ml} \mathrm{min}$.

Preparation of extracts for estimations. A concentrated suspension of Methylococcus sp. was sonicated using an MSE ultrasonic disintegrator ( $5 \times \mathrm{I} \mathrm{min})$, and centrifuged at $17000 \mathrm{~g}$ for $15 \mathrm{~min}$ at $4{ }^{\circ} \mathrm{C}$; the clear supernatant was decanted.

Estimations. (i) Total culture carbon and supernatant carbon were estimated with a Beckman model 915 total organic carbon analyser. Analyses were made of the whole culture and of culture supernatant after centrifugation $\left(17000 \mathrm{~g}, 15 \mathrm{~min}, 4^{\circ} \mathrm{C}\right.$ ) and the carbon content of the bacteria was obtained from the difference.

(ii) The protein contents of culture supernatant and cell-free extracts were usually determined by the method of Lowry et al. (1951). The method of Warburg \& Christian (1969) was also used.

(iii) Amino acids. Freeze-dried samples (100 $\mathrm{mg}$ ) were refluxed in a $500 \mathrm{ml}$ round-bottomed flask with $180 \mathrm{ml} 5.9 \mathrm{M}-\mathrm{HCl}$ on an oil-bath for $24 \mathrm{~h}$. The condenser was washed down with a little deionized water and the warm hydrolysate was filtered under pressure through Whatman no. 54I filter paper. The hydrolysate was transferred quantitatively to a volumetric flask and made up to $250 \mathrm{ml}$ with deionized water. Samples $(2 \mathrm{ml})$ of the hydrolysate were then dried in vacuo over $\mathrm{KOH}$ and $\mathrm{H}_{2} \mathrm{SO}_{4}$. The residue was redissolved in $2 \mathrm{ml} \mathrm{O} . \mathrm{I} \mathrm{M}-\mathrm{HCl}$ containing $\mathrm{O} . \mathrm{I} \mu \mathrm{mol}$ norleucine $\mathrm{ml}^{-1}$ and I ml was put on to a column $(130 \times 0.6 \mathrm{~cm}$, Technicon type A chromobeads). A Technicon model NC-I amino acid analyser, using the standard autograd composition for a $17 \mathrm{~h}$ run at $60^{\circ} \mathrm{C}$, was used.

(iv) Nucleic acid. Freeze-dried bacteria $(50 \mathrm{mg})$ were suspended in $2.5 \mathrm{ml}$ distilled water and then extracted sequentially as follows: $7.5 \mathrm{ml} 10 \%(\mathrm{w} / \mathrm{v})$ trichloroacetic acid, $c{ }^{\circ} \mathrm{C}$, twice; $80 \%(\mathrm{v} / \mathrm{v})$ and $95 \%$ ethanol, $\circ{ }^{\circ} \mathrm{C}$; a boiling ether/ethanol mixture (3:I, v/v), three times; and $5 \%$ trichloroacetic acid, $90{ }^{\circ} \mathrm{C}$, for $15 \mathrm{~min}$. The bacteria were centrifuged at $17000 \mathrm{~g}$ for $15 \mathrm{~min}$ between each extraction. The supernatant from the final centrifugation contained RNA and DNA. The RNA and DNA in the extracts were determined by the diphenylamine and orcinol colorimetric methods respectively using yeast RNA and calf thymus DNA (Sigma) as standards (Herbert, Phipps \& Strange, 1971). The nucleic acid content of the culture supernatant was determined by the method of Warburg \& Christian (1969) because the compounds present in the culture supernatant interfered severely with the diphenylamine and orcinol colorimetric methods.

(v) Formate and formaldehyde in culture supernatants were assayed by the methods of Lang \& Lang (1972) and Chrastil \& Wilson (1975) respectively. The limits of detection for formate and formaldehyde were II $\mathrm{mg} \mathrm{l}^{-1}$ and $\mathrm{x}^{\cdot} \cdot 3 \mathrm{mg}^{-1}$ respectively.

(vi) Methanol in culture supernatants was determined by gas-liquid chromatography, using a Varian $\mathrm{I} 800$ series chromatograph and a Poropak $\mathrm{Q}$ column at $160^{\circ} \mathrm{C}$. The limit of detection was $10 \mathrm{mg}$ methanol $\mathbf{1}^{-1}$.

Gel electrophoresis. Samples ( 50 to $100 \mu \mathrm{l}$ ) of culture supernatant and cell-free extract (0.2 $\mathrm{mg}$ protein) were examined using polyacrylamide gel electrophoresis with and without sodium dodecyl sulphate (SDS) (Shapio, Viñuela \& Maizel, 1967). The gels were stained with $0.25 \%$ Coomassie blue for $3 \mathrm{~h}$, destained with $10 \%(\mathrm{v} / \mathrm{v})$ acetic acid and then scanned at $620 \mathrm{~nm}$ in a Gilford spectrophotometer. Unstained gels were scanned at $280 \mathrm{~nm}$.

Paper chromatography. The presence of free amino acids in the culture supernatant (concentrated $\times 40$ by rotary evaporation at $25^{\circ} \mathrm{C}$ ) was detected by paper chromatography, using a solvent system consisting of butanol/acetic acid/water (12:3:5, by vol.). The paper was sprayed with $0.25 \%(\mathrm{w} / \mathrm{v})$ ninhydrin in $95 \%$ ethanol and developed at $100{ }^{\circ} \mathrm{C}$ for $10 \mathrm{~min}$.

Extracellular enzymic activity. Deoxyribonuclease activity was detected using Oxoid DNase agar, CM $32 \mathrm{I}$. Ribonuclease activity was detected using RNAase agar of the following composition $\left(\mathrm{g} \mathrm{l}^{-1}\right)$ : Tryptose (Oxoid 
L47), 20.0; Torula yeast RNA (Sigma, type II-5), 5.0; NaCl, 5.0; and Oxoid agar no. 3, 12.0; pH 7.3. Lipolytic activity was detected using Oxoid Tributyrin agar $\left(\mathbf{P M}_{4}\right)$.

The heterotrophic micro-organisms were grown individually in lysate broth. Upon reaching the stationary phase, the cultures were centrifuged for $30 \mathrm{~min}$ at $17000 \mathrm{~g}$ and the clear, bacteria-free supernatants were tested for their extracellular proteolytic, RNAase, DNAase and lipolytic activities. This was achieved by placing $0.1 \mathrm{ml}$ of culture supernatant (concentrated $\times 10$ by rotary evaporation at $25^{\circ} \mathrm{C}$ ) in wells cut into agar plates containing casein, DNA, RNA and tributyrin, which were then incubated at $42{ }^{\circ} \mathrm{C}$ for $72 \mathrm{~h}$. Chloramphenicol $\left(0.005 \mathrm{~g} \mathrm{l}^{-1}\right)$ was added to the culture supernatant and the agar to prevent bacterial growth. Casein agar and tributyrin plates are opaque, and positive proteolytic and lipolytic activity was evident as clear zones around the well containing the supernatant. After incubation the RNA and DNA agar plates were flooded with $\mathrm{I} \mathrm{M}-\mathrm{HCl}$, which reacted with nucleic acid in the medium and formed a cloudy precipitate: Wells containing DNAase and RNAase were surrounded by a clear area.

Peptidase activity of bacterial suspensions was detected by the method of Bürger (1967), using DL-alanine$\beta$-naphthylamide as substrate.

Assay of proteolytic activity. Proteolytic activity in the culture supernatants obtained from chemostat cultures was determined by the method of Rinderknecht et al. (1968) using Streptomyces griseus protease V (Sigma) as a reference of activity $\left(\mathrm{I} \mathrm{mg} \mathrm{ml} \mathrm{m}^{-1}=1.2\right.$ units). The $\mathrm{pH}$ of the sample in Tris buffer $(0.05 \mathrm{M})$ was adjusted to different values with I $\mathrm{M}-\mathrm{HCl}$ or $\mathrm{I} \mathrm{M}-\mathrm{NaOH}$ before addition of the RBD-Hide protein. The samples were then incubated for $\mathrm{I} \mathrm{h}$ at $42{ }^{\circ} \mathrm{C}$ on a shaker and filtered through glass wool, and the colour intensity was read at $595 \mathrm{~nm}$. Culture supernatant was also added to Tris buffer containing various concentrations of EDTA and incubated for $30 \mathrm{~min}$ at $42{ }^{\circ} \mathrm{C}$ before assaying for proteolytic activity, which was carried out in the presence of a predetermined concentration of EDTA. Samples with low activity were incubated for $2 \mathrm{~h}$.

Measurement of $K_{\mathrm{m}}$ values. The effect of various concentrations of methane and methanol on the respiration rate of samples taken from chemostat cultures were determined using an oxygen electrode cell (Harrison, 1973) and $K_{\mathrm{m}}$ values for methane and methanol were calculated.

\section{RESULTS}

\section{Effect of dilution rate on bacterial carbon and culture supernatant carbon}

The concentrations of bacterial carbon and culture supernatant carbon in an ammonialimited culture of Methylococcus sp. at various dilution rates are shown in Fig. I. The concentration of bacterial carbon decreased slightly and the culture supernatant carbon decreased markedly with increasing dilution rate. The ratio of bacterial carbon to culture supernatant carbon was directly proportional to the dilution rate indicating that relatively more carbon was excreted into the culture supernatant at low growth rates. In the methaneutilizing mixed culture the concentration of bacterial carbon again decreased slightly with increasing dilution rate (from $\mathrm{I} \cdot 25 \mathrm{~g} \mathrm{l}^{-1}$ at $0.08 \mathrm{~h}^{-1}$ to $\mathrm{I} \cdot 07 \mathrm{~g} \mathrm{l}^{-1}$ at $0.2 \mathrm{~h}^{-1}$ ), but the culture supernatant carbon was independent $\left(0 \cdot \mathrm{I}^{2} \mathrm{~g}^{-1}\right)$ of dilution rate.

The amount of bicarbonate in the culture supernatant depends upon the $\mathrm{pH}$ and the partial pressure of $\mathrm{CO}_{2}$ in the gas phase (Umbreit, Burris \& Stauffer, 1972). The chemostat was operated at pH 6.8 and a $\mathrm{CO}_{2}$ concentration of approximately $2.5 \%$ in the gas phase. Under these conditions bicarbonate and $\mathrm{CO}_{2}$ constituted approximately $0.02 \mathrm{~g}$ carbon $1^{-1}$ in the culture supernatant of Methylococcus sp.

Methanol was not detected in the culture supernatant of the methane-utilizing bacterium Methylococcus sp. This organism had a high affinity for both methane and methanol, with $K_{\mathrm{m}}$ values of 32 and $4 \mathrm{I} \cdot 6 \mu \mathrm{M}$ respectively. The $K_{\mathrm{m}}$ values for methane and methanol in the mixed culture containing four heterotrophic bacteria were 44 and $40 \mu \mathrm{M}$ respectively. Although both a pure culture of Methylococcus sp. and the mixed culture oxidized formate with an apparent $K_{\mathrm{m}}$ value of $\mathrm{I} \cdot 5 \mathrm{mM}$, no formate was detected (i.e. $<\mathrm{II} \cdot 5 \mathrm{mg} \mathrm{l}^{-1}$ ) in the culture effluent of either culture. The concentration of formaldehyde in culture supernatants of Methylococcus sp. was less than $5 \mathrm{mg}^{1-1}$.

The amount of protein and nucleic acid in the culture supernatant of Methylococcus sp. exhibited a similar relationship with dilution rate to that observed for whole freeze-dried bacteria (Fig. 2a,b). Since different methods were used to determine the protein and nucleic 


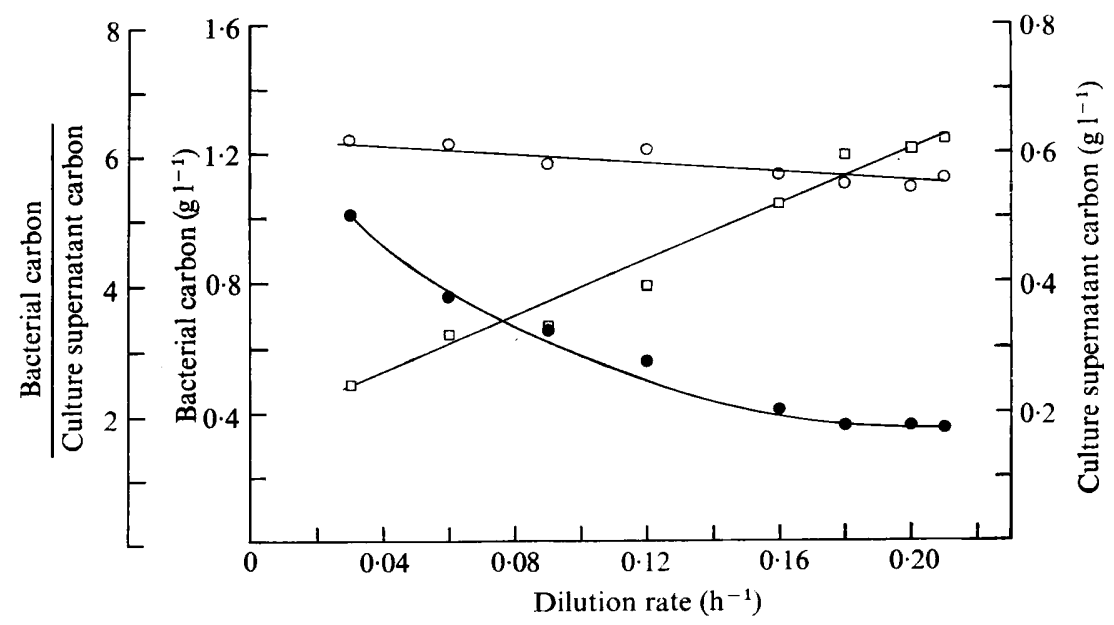

Fig. I. Steady state values for bacterial carbon $(O)$ and culture supernatant carbon $(\theta)$ and the ratio of bacterial carbon to culture supernatant carbon $(\square)$ as functions of the dilution rate of an ammonia-limited chemostat culture of Methylococcus sp. Each point represents the average obtained on analysis of two to ten samples.

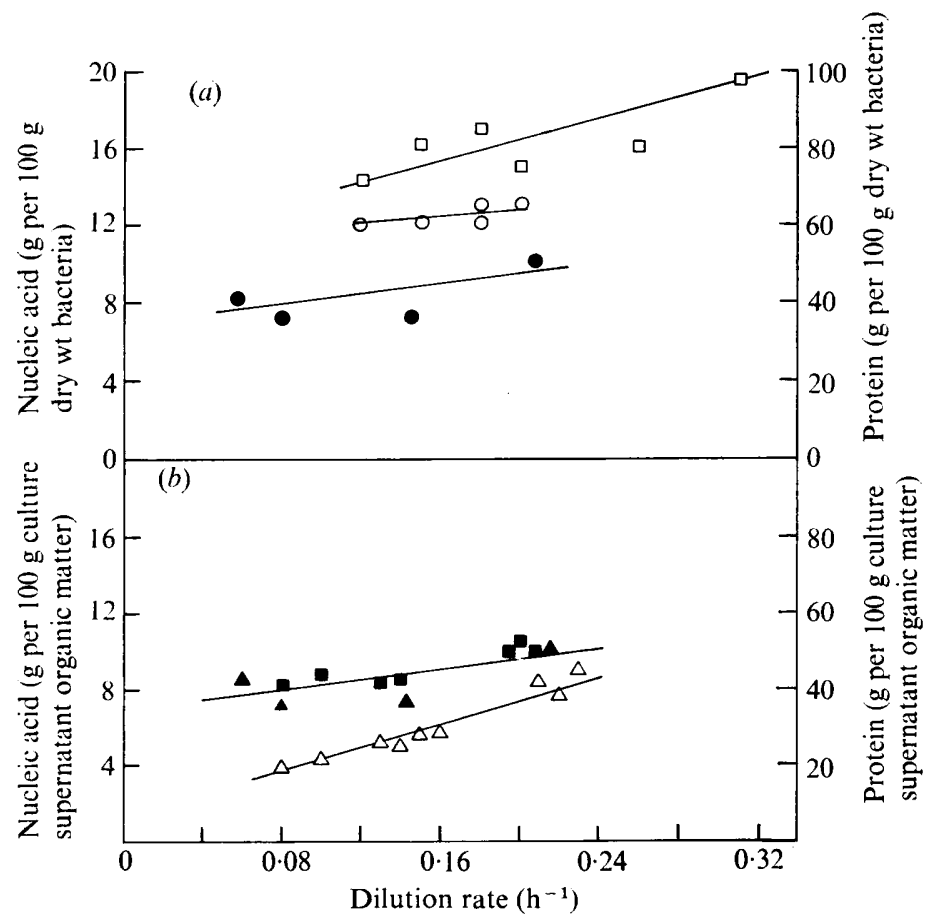

Fig. 2. Concentration of nucleic acid and protein in the culture supernatant and in samples of freezedried bacteria taken from an ammonia-limited chemostat culture of Methylococcus sp. grown at various dilution rates. $(a) \bigcirc$, Protein calculated from the summation of amino acid content (g per $\mathrm{I} 00 \mathrm{~g}$ dry wt bacteria); 9 , protein determined by the method of Lowry et al. (I95I) (g per $100 \mathrm{~g}$ dry wt bacteria); $\square$, nucleic acid (DNA + RNA) (g per $100 \mathrm{~g}$ dry wt bacteria.) (b) $\mathbf{}$, Protein determined by the method of Warburg \& Christian (1969) (g per $100 \mathrm{~g}$ dry wt culture supernatant organic matter, assuming that organic matter $=46 \%$ carbon); $\triangle$, nucleic acid (g per $100 \mathrm{~g}$ dry wt culture supernatant organic matter); $\Delta$, protein determined by the method of Lowry et al. (195I) ( $g$ per $100 \mathrm{~g}$ dry wt culture supernatant organic matter). Each point represents the average obtained on analysis of two to ten samples. 
Table I. Effect of EDTA on the proteolytic activity of culture supernatants taken from chemostat cultures containing Methylococcus sp. and various combinations of heterotrophic bacteria

\begin{tabular}{|c|c|c|c|c|}
\hline \multirow{3}{*}{ Organisms } & \multicolumn{4}{|c|}{ Activity ( $\%$ of control) } \\
\hline & $\ldots$ & 8 & 80 & 800 \\
\hline & 78 & 68 & 0 & 0 \\
\hline $\begin{array}{l}\text { Methylococcus sp. }+ \\
\text { heterotroph NCIBI I } 310\end{array}$ & 92 & 63 & 8 & o \\
\hline $\begin{array}{l}\text { Methylococcus sp. }+ \\
\text { heterotroph NCIBI I } 307\end{array}$ & 78 & 37 & 0 & 0 \\
\hline $\begin{array}{l}\text { Methylococcus sp. }+ \\
\text { heterotrophs NCIBI I } 310 \text {, NCIBI I } 307 \text {, } \\
\text { NCIBI I } 308 \text { and NCIBI } 1309\end{array}$ & 80 & 29 & 13 & 0 \\
\hline
\end{tabular}

acid present in the culture supernatant and freeze-dried bacteria, the total values observed are not comparable. To clarify this, the amounts of protein in the culture supernatant and hydrolysates of freeze-dried bacteria were measured and found to be comparable using the method of Lowry et al. (I95I) (Fig. $2 a, b$ ).

\section{Gel electrophoresis}

SDS-polyacrylamide gel electrophoresis of cell-free extracts of whole bacteria, and of culture supernatants indicated the presence of a similar range of proteins in both samples. Polyacrylamide gel electrophoresis (without SDS) of culture supernatants after growth of Pseudomonas NCIBII3IO in Methylococcus sp. lysate broth indicated that this organism removed most of the protein present. Moreover, no free amino acids were detected in the culture supernatant using paper chromatography, but a spot was observed at the origin. Hydrolysis of the supernatant released a wide range of free amino acids detected by paper chromatography. Thus the primary heterotroph, Pseudomonas NCIBII3IO, hydrolysed most of the high molecular weight protein, but a residual amount of polypeptide, not detected by gel electrophoresis, remained in the culture supernatant.

\section{Extracellular enzymic activity}

The four heterotrophic bacteria were grown in lysate broth to the stationary phase and were then centrifuged. The bacteria-free supernatant was tested for proteolytic, nuclease and lipolytic activity and whole bacteria were tested for peptidase activity.

Between them, the four organisms possessed the necessary enzymes to utilize the major organic compounds present in the culture supernatant of the methane-utilizing bacterium, Methylococcus sp. Pseudomonas NCIBI I 3 IO and NCIBI 1309 were proteolytic (extracellular), Pseudomonas NCIBI I 310 and Mycobacterium/Nocardia NCIBI I 307 had extracellular DNAase activity and the latter organism also had RNAase activity. Extracellular lipolytic activity was observed for Pseudomonas NCIBI 1309 and all four organisms had peptidase activity.

Chemostat cultures containing various combinations of heterotrophic bacteria with the Methylococcus sp. were set up and the culture supernatant was assayed for proteolytic activity using the method of Rinderknecht et al. (1968). The Methylococcus sp. plus the predominant heterotrophic bacterium Pseudomonas NCIBI 13 IO exhibited strong proteolytic activity [0.43 units (mg protein) ${ }^{-1}$ ], with a pH optimum at 7.65 . A low level of proteolytic activity [0.0I6 units (mg protein) ${ }^{-1}$ ] was detected in culture supernatants of Methylococcus sp. and a $\mathrm{pH}$ optimum of $\mathbf{9 \cdot 2}$ was observed. This was unchanged in the presence of Mycobacterium/Nocardia NCIBI 1307 but, when Methylococcus sp. cells were lysed by sonication and the lysate was incubated in Tris/HCl buffer at $\mathrm{pH} 7.65$ or 9.2 for $24 \mathrm{~h}$, the protein profile (of SDS gels) remained unchanged, indicating the absence of proteases necessary to degrade the native proteins. The proteolytic activity in the culture containing four heterotrophic 
bacteria was higher [0.60 units (mg protein) $\left.{ }^{-1}\right]$ than that observed for the culture containing Methylococcus sp. plus Pseudomonas NCIBII3IO; this was attributed to the proteolytic activity of Pseudomonas NCIBII 309 as it was the only other organism in the mixed culture shown to produce extracellular protease. EDTA $(0.8 \mathrm{~mm})$ completely inhibited the proteolytic activity present in culture supernatants of the methane-utilizing bacterium and various combinations of the methane utilizer plus the four heterotrophic bacteria (Table I).

\section{DISCUSSION}

It has been suggested that the increased stability of mixed cultures of methane-utilizing bacteria and heterotrophs is due to the utilization of inhibitory intermediate oxidation products of methane by the heterotrophic bacteria (Pirt, 1972; Wilkinson \& Harrison, 1973). In our study methanol and formate were not detected in culture supernatants of the methaneutilizing bacterium Methylococcus sp. Moreover, the $K_{\mathrm{m}}$ values for methane and methanol of the methane-utilizing pure and mixed cultures were similar. Although formaldehyde was detected ( $<5 \mathrm{mg} \mathrm{l}^{-1}$ ) in culture supernatants of Methylococcus sp., it constituted a very small proportion of the organic carbon in the culture supernatant. However, the possibility that low levels of other products of methane oxidation are excreted by the methane utilizer cannot be excluded. The organic compounds present in the culture supernatant of the methane-utilizing organism could be accounted for largely as protein and nucleic acid. The relationship between dilution rate and the concentrations of protein and nucleic acid in the culture supernatant and whole cells of Methylococcus sp. was similar. Moreover, the culture supernatant did not contain a single protein but a mixture of proteins which on SDS-polyacrylamide gels had a similar profile to the proteins extracted from whole Methylococcus sp. cells. This suggests that these compounds originated from lysis of the methaneutilizing bacteria and a clear relationship between growth rate and bacterial lysis was evident. Dostalek \& Molin (I975) reported an increase in the culture supernatant carbon with decreasing growth rate for a methanol-limited chemostat culture of Methylomonas methanolica and attributed this to the excretion of extracellular carbon compounds. These compounds were not identified and an alternative explanation may be bacterial lysis.

The four heterotrophic bacteria present in the mixed culture constituted approximately $14 \%$ of the total population and possessed between them extracellular proteases and nucleases, as well as lipases and peptidases. It is possible that these enzymes reduce the amount of carbon in the culture supernatant to a low level which is independent of dilution rate. One explanation for the presence of residual carbon in the culture supernatant of the mixed culture is that it is derived from minor cell constituents which are individually present at concentrations too low to be utilized by the heterotrophic organisms.

The reason for lysis of the methane-utilizing organism is not known and may be an artefact of chemostat culture. However, it may be a more general phenomenon, only observed in methylobacteria because these organisms do not utilize complex organic molecules to any extent and therefore do not remove them from the culture supernatant. Methylococcus sp. did not appear to contain native proteases that degraded cellular proteins upon bacterial lysis. This may be an evolutionary adaptation as several organic compounds, including amino acids, inhibit the growth of Methylococcus capsulatus (Eccleston \& Kelly, 1972; Eroshin, Harwood \& Pirt, 1968).

The protein present in the culture supernatant was degraded largely by the extracellular protease produced by Pseudomonas NCIBI 13 Io. This protease has a $\mathrm{pH}$ optimum and sensitivity to EDTA characteristic of neutral proteases (Keay \& Wildi, I970), which often require zinc and calcium ions (Matsubara \& Feder, 1971). Thus in a complex mixed culture system in which extracellular enzymes play an important role, the stability of the culture may be dependent on the concentration of various inorganic ions that do not play an important role in the metabolism of the primary organism. 
I would like to thank Drs D. E. F. Harrison and J. W. Drozd for many useful discussions and Mr L. J. Barnes and Mr N. Crabtree for assistance with the chemical analysis of bacterial constituents.

\section{REFERENCES}

BÜRGER, H. (1967). Biochemische Leistungen nichtproliferierender Mikro-organismen. III. Nachweis von Arylsufatasen und Peptidasen. Zentralblatt für Bakteriologie, Parasitenkunde, Infektionskrankheiten und Hygiene (Abteilung I) 202, 395-40I.

Chrastil, J. \& Wilson, J. T. (1975). A sensitive colorimetric method for formaldehyde. Analytical Biochemistry 63, 202-207.

Dostalek, M. \& Molin, N. (1975). Studies of biomass production of methanol oxidizing bacteria. In Single Cell Protein, vol. II, pp. 385-40I. Edited by S. R. Tannenbaum and D. I. C. Wang. Cambridge, Massachusetts and London: MIT Press.

Eccleston, M. \& Kelly, D. P. (1972). Assimilation and toxicity of exogenous amino acids in the methane-oxidizing bacterium Methylococcus capsulatus. Journal of General Microbiology 7x, $54 \mathrm{I}-554$.

Eroshin, V. K., Harwood, J. H. \& Pirt, S. J. (1968). Influence of amino acids, carboxylic acids and sugars on the growth of Methylococcus capsulatus on methane. Journal of Applied Bacteriology 3I, 560-567.

Hamer, G., Harrison, D. E. F., Topiwala, H. H. \& GABRIEL, A. (1976). The conversion of natural gas into protein for use in compounded animal feeds. Institute of Chemical Engineering Symposium Series 44, 65-72.

HARRISON, D. E. F. (1973). Studies on the affinity of methanol- and methane-utilising bacteria for their carbon substrates. Journal of Applied Bacteriology 36, 30I-308.

Harrison, D. E. F., Topiwala, H. H. \& Hamer, G. (1972). Yield and productivity in single-cell protein production from methane and methanol. Proceedings of the 4th International Fermentation Symposium, Kyoto, Japan, pp. 491-495. Edited by G. Terui. Japan: Society of Fermentation Technology.

Harrison, D. E. F, Wilkinson, T. G., Wren, S. J. \& HARWOOD, J. H. (1975). Mixed bacterial cultures as a basis for continuous production of single cell protein from $\mathrm{C}_{1}$ compounds. Continuous Culture 6. Applications and New Fields, pp. 122-134. Edited by A. C. R. Dean, D. C. Ellwood, C. G. T. Evans and J. Melling. Chichester: Ellis Horwood.
Herbert, D., Phipps, P. J. \& Strange, R. E. (I97I). Chemical analysis of microbial cells. Methods in Microbiology 5B, 210-344.

Keay, L. \& WiLdi, B. S. (1970). Proteases of the genus Bacillus. I. Natural proteases. Biotechnology and Bioengineering 12, $179-212$.

LANG, E. \& LANG, H. (1972). Spezifische Farbreaktion zum direkten Nachweis der Ameisensaure. Zeitschrift für analytische Chemie 260, 8-10.

Lowry, O. H., Rosebrough, N. J., FARR, A. L. \& RANDALL, R. J. (I95I). Protein measurement with the Folin phenol reagent. Journal of Biological Chemistry 193, 265-275.

MatsubarA, M. \& Feder, J. (197I). Other bacterial, mold and yeast proteases. In The Enzymes, vol. III, 3rd edn, pp. 72I-795. Edited by P. D. Boyer. New York and London: Academic Press.

PIRT, S. J. (I972). Prospects and problems in continuous flow culture of micro-organisms. Journal of Applied Chemistry and Biotechnology 22, 5564.

Rinderknecht, H., Geokas, M. C., Silverman, P. \& HaVerback, B. J. (I968). A new ultrasensitive method for the determination of proteolytic activity. Clinica chimica acta 21, 197-203.

Shapio, A. L., Viñuela, E. \& Maizel, J. V. (1967). Molecular weight estimation of polypeptide chains by electrophoresis in SDS-polyacrylamide gels. Biochemical and Biophysical Research Communications 28, 815-820.

Sheehan, B. T. \& Johnson, M. J. (197I). Production of bacterial cells from methane. Applied Microbiology 15, 1473-1478.

UMbreit, W. W., BurRis, R. H. \& STAufFer, J. R. (1972). Manometric and Biochemical Techniques. $5^{\text {th }}$ edn, pp. 20-29. Minneapolis, Minnesota: Burgess Publishing Company.

WARBURG, O. \& Christian, W. (1969). Spectrophotometric and turbidimetric methods. Methods in Enzymology III, 45 I-454.

Wilkinson, T. G. \& Harrison, D. E. F. (1973). The affinity for methane and methanol of mixed cultures grown on methane in continuous culture. Journal of Applied Bacteriology 36, 309-313.

Wilkinson, T. G., Topiwala, H. H. \& Hamer, G. (1974). Interactions in a mixed bacterial population growing on methane in continuous culture. Biotechnology and Bioengineering 16, 4I-49. 